82 Howes OD, Bhatnagar A, Gaughran FP, Amiel SA, Murray RM, Pilowsky LS. A prospective study of impairment in glucose control caused by clozapine without changes in insulin resistance. Am J Psychiatry 2004; 161: 361-3.

83 Reynolds GP, Zhang Z, Zhang XB. Association of antipsychotic drug-induced weight gain with a $5-\mathrm{HT} 2 \mathrm{C}$ receptor gene polymorphism. Lancet 2002; 359 ; 2086-7

84 Kim SF, Huang AS, Snowman AM, Teuscher C, Snyder SH. From the Cover: Antipsychotic drug-induced weight gain mediated by histamine $\mathrm{H} 1$ receptorlinked activation of hypothalamic AMP-kinase. Proc Natl Acad Sci USA 2007; 104: 3456-9.

85 Kinon BJ, Kaiser CJ, Ahmed S, Rotelli MD, Kollack-Walker S. Association between early and rapid weight gain and change in weight over one year of olanzapine therapy in patients with schizophrenia and related disorders. J Clin Psychopharmacol 2005; 25: 255-8.
86 Stern MP, Fatehi P, Williams K, Haffner SM. Predicting future cardiovascular disease: do we need the oral glucose tolerance test? Diabetes Care 2002 25: 1851-6.

87 Wilson PW, Meigs JB, Sullivan L, Fox CS, Nathan DM, D'Agostino RB. Prediction of incident diabetes mellitus in middle-aged adults: the Framingham Offspring Study. Arch Intern Med 2007; 167: 1068-74.

88 Schmidt MI, Duncan BB, Bang $\mathrm{H}$, Pankow JS, Ballantyne CM, Golden SH, et al. Identifying individuals at high risk for diabetes: the Atherosclerosis Risk in Communities study. Diabetes Care 2005; 28: 2013-8.

89 Ginsberg HN. Insulin resistance and cardiovascular disease. J Clin Invest 2000; 106: 453-8.

90 Cooper SJ, Reynolds GP, Barnes T, England E, Haddad PM, et al. BAP guidelines on the management of weight gain, metabolic disturbances and cardiovascular risk associated with psychosis and antipsychotic drug treatment. J Psychopharmacol 2016; 30: 717-48.

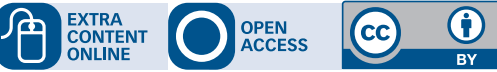

\title{
T2 Trainspotting: addiction in a digital age
}

\section{Peter Byrne}

Renton (Ewan McGregor) - the fifth main character in the original film and in this sequel - returns to Edinburgh from 20 years in Amsterdam with a bitter monologue:

'Choose life

Choose Facebook, Twitter, Instagram and hope that someone, somewhere cares

choose looking up old flames, wishing you'd done it all differently

And choose watching history repeat itself

Choose your future

Choose reality TV, slut shaming, revenge porn

Choose a zero hour contract, a two hour journey to work

And choose the same for your kids, only worse, and smother the pain with an unknown dose

of an unknown drug made in somebody's kitchen

And then .... take a deep breath

You're an addict, so be addicted

Just be addicted to something else

choose the ones you love

Choose your future

Choose life'

In revisiting the original film's characters, writer John Hodge adapting Irving Welsh serves us a portion of only the first half of the 'learning and hugging' formula of US sitcom. Renton has acquired self-knowledge and Simon (Jonny Lee Miller) knows his new drug of choice, cocaine, traps him in his narrative where his 'best friend ruined [his] life'. In a key scene, simon reminds Renton that he sold heroin to their friend Tommy who died a lonely drug-related death in the first film, but Renton retorts with the death of Simon's baby Dawn - again collateral damage of heroin use. Choose death. But when they score money, they score some novel psychoactive agents and shoot up again, though in nicer environs, with big screen TV and nostalgia-pumping speakers. Their friend Spud Murphy (Ewen Bremmer) struggles even harder with his addiction but ultimately finds his voice as chronicler of this Underworld. Even their mutual fiend, Franco Begby (Robert Carlyle) - who cannot resist blue collar criminality and violent revenge - learns not to revisit the damage on his son that he himself had suffered from his addicted father.

The sequel avoids its plot's motif 'first there was an opportunity... then there was a betrayal'. It revisits the fierce musicality of the original Trainspotting and fills the screen with visual nods to the film that nailed 1990s UK. Some critics cite the social media of Renton's rant as the new addiction, but the film has lots to say about other modern afflictions: gentrification, globalisation, gym treadmills, the sex industry, cybercrime, webcams and CCTV. Its four female characters have little to do, as agents of the men though one has the last laugh. The main grumble is how well three junkies look 21 years later: in our reality, they should be dead or struggling from ravages of risks taken. But this creative team has not betrayed the original. Director Danny Boyle has brought Renton home.

T2 Trainspotting directed by Danny Boyle, UK release 2017, distributed by Tristar Pictures. 